\title{
Rapid aerobic granulation using biochar for the treatment of petroleum refinery wastewater
}

\author{
Xin Wang ${ }^{1}$. Jie Ming ${ }^{1}$. Chun-Mao Chen ${ }^{1}$ Brandon A. Yoza ${ }^{2}$ Q Qian-Wei Li ${ }^{1}$ Jia-Hao Liang ${ }^{1} \cdot$ Geoffrey Michael Gadd ${ }^{3}$. \\ Qing-Hong Wang ${ }^{1}$
}

Received: 14 April 2020 / Published online: 28 August 2020

(c) The Author(s) 2020

\begin{abstract}
Aerobic granular sludge technology has great potential for the treatment of petroleum refinery wastewater. However, strategies to shorten the granulation time and improvement the stability still need to be developed. In this work, biochar was prepared from waste petroleum activated sludge (biochar-WPS) and used in a sequencing batch reactor for the treatment of petroleum refinery wastewater. Biochar-WPS presented the surface area of $229.77 \mathrm{~m}^{2} / \mathrm{g}$, pore volume of $0.28 \mathrm{~cm}^{3} / \mathrm{g}, \mathrm{H} / \mathrm{C}$ and O/C atomic ratios of 0.42 and 0.21 , respectively. The porous structure and a high degree of hydrophilicity were found to facilitate microbial colonization and adhesion as well as particle aggregation. Application of biochar-WPS resulted in the formation of more substantial and stable aerobic granules ( $66 \%$ of granules $>0.46 \mathrm{~mm}$ diameter) 15 days earlier compared with the control. The addition of biochar-WPS enhanced the average removal efficiency of chemical organic demand ( $3 \%)$, oil ( 4\%) and total nitrogen $(\sim 10 \%)$ over the control. Increased microbial richness and diversity were observed within the formed granules and had an increased ( $4 \%)$ proportion of denitrifying bacteria. These results indicate that an aerobic granulation mechanism using biochar-WPS is a feasible option for the treatment of petroleum refinery wastewater.
\end{abstract}

Keywords Biochar $\cdot$ Petroleum refinery wastewater $\cdot$ Petroleum activated sludge $\cdot$ Granular sludge $\cdot$ Denitrifying bacteria

\section{Introduction}

Crude oil refining results in the generation of large quantities of wastewater (Petroleum Refinery Wastewater, PRW), often with a complex chemical compositions and poor biodegradability (Kaiser 2017). PRW contains abundant organics substrates such as hydrocarbons, naphthenic acid and

Edited by Xiu-Qiu Peng

Electronic supplementary material The online version of this article (https://doi.org/10.1007/s12182-020-00499-x) contains supplementary material, which is available to authorized users.

Qing-Hong Wang

wangqhqh@163.com

1 State Key Laboratory of Heavy Oil Processing, State Key Laboratory of Petroleum Pollution Control, China University of Petroleum-Beijing, Beijing 102249, China

2 Hawaii Natural Energy Institute, University of Hawaii at Manoa, Honolulu, HI 96822, USA

3 Geomicrobiology Group, School of Life Sciences, University of Dundee, Dundee DD1 5EH, Scotland, UK heterocyclic compounds as well as nitrogen-containing compounds which are mainly removed through biological treatment methods (Wang et al. 2016). The most common biological treatment processes utilize activated sludge (anoxic/ oxic process, anaerobic/anoxic/oxic process). These established processes are generally straightforward in operation but limited by low biomass retention, inefficient efficiency and significant space.

Aerobic granular sludge (AGS) technology has been widely concerned in the treatment of industrial and municipal wastewaters (Rosman et al. 2013; Cetin et al. 2018). In comparison with conventional activated sludge, AGS exhibits enhanced settleability, higher biomass retention and improved resistance to shock loading of pollutants (Rosman et al. 2013). Our previous research has demonstrated that AGS can be used for the treatment of PRW (Chen et al. 2019). However, the development of AGS requires long acclimation of glucose as co-substrate. Similar results were also found in the treatment of oil wastewater. For example, granules were only observed after 110 days operation during the treatment of palm oil mill wastewater (Gobi et al. 2011). Therefore, reducing the 
start-up time is critical for further development and use of AGS technology for the treatment of refinery and other wastewaters.

According to the nuclei hypothesis, support materials can provide nuclei that facilitate bacteria adhesion and aggregation (Lettinga et al. 1980). Therefore, a variety of porous materials with rough surface area have been used in attempts to improve the granulation process. Heterogeneous solids such as crushed or intact granules, magnetic nanoparticles and granular activated carbon (GAC) have all been successfully applied in accelerating aerobic granulation (Liang et al. 2017; Li et al. 2013; Pijuan et al. 2011; Zou et al. 2019).

Biochar, produced from pyrolysis of biomass has a microporous structure and has been widely used in soil remediation and wastewater treatments as an adsorbent, support matrix and catalyst carrier (Li et al. 2017; Taskin et al. 2019; Shi et al. 2019; Dai et al. 2018; Zhang et al. 2018a). More attention has been paid to the conversion of biochars from waste activated sludge, acting as adsorbent, catalyst carrier and conductive materials to facilitating interspecies electron transfer due to their large specific surface area, high stability and electrical conductivity (Yang et al. 2018; Zhang et al. 2018a, b). For example, biochar prepared with petroleum waste-activated sludge (WPS) showed high catalytic efficiency as catalyst in catalytic ozonation of PRW (Chen et al. 2019). Wang et al. (2018) got successfully micro-/ mesoporous-enriched biochar adsorbents prepared from a mixture of petroleum-derived oily sludge and biomass. It clearly has application prospects for aerobic sludge granulation due to the physico-chemical characteristics of large specific surface area, stable structure and low cost. It may expand the application of biochar and reduce/recycle the WPS, achieving the concept of "waste control by waste." Biochars derived from different materials vary greatly in their physico-chemical properties, including surface chemistry, porosity and elemental composition. The characteristics of biochar-WPS, its potential to affect sludge granulation, and the mechanism involved should be investigated.

In the present research, following the "waste control by waste" concept, biochar derived from waste petroleum refinery sludge (biochar-WPS) was prepared and used for the treatment of refinery wastewater. The physico-chemical properties of biochar-WPS were analyzed, including pore structure, elemental composition and surface functional groups. The biochar-WPS was added into a sequencing batch reactor (SBR) as a support material for the treatment of PRW. Organic compound and nitrogen $\left(\mathrm{NH}_{4}{ }^{+}-\mathrm{N}\right.$ and $\mathrm{TN})$ removal efficiencies, granule characteristics and the microbial communities that developed were determined to assess the influence of biochar-WPS on AGS formation and reactor performance. Furthermore, a possible mechanism for biochar-mediated aerobic granulation has been proposed based on our results.

\section{Materials and methods}

\subsection{Biochar preparation and inoculated sludge}

Waste petroleum-activated sludge was obtained from the Liaohe Petrochemical Wastewater Treatment Plant (Panjin, Liaoning, China). The biochar was obtained according to the methods described by Ming et al. (2020). Briefly, raw sludge was oven-dried and pyrolyzed at $700{ }^{\circ} \mathrm{C}$ for $3 \mathrm{~h}$ under $\mathrm{N}_{2}$ and then was immersed in $\mathrm{HCl}$ solution (w/w, 3\%) for $24 \mathrm{~h}$. After washing with ultrapure water until a $\mathrm{pH}$ value of 7.0, the samples were oven-dried and screened using 100 mesh and 200 mesh sieves. The prepared biochar was named biochar-WPS.

The seed sludge was obtained from a aeration tank at Jinxi Petrochemical Company Wastewater Treatment Plant (Huludao, Liaoning, China), with a mixed liquor suspended solids (MLSS) of $3000 \mathrm{mg} / \mathrm{L}$, mixed liquor volatile suspended solids (MLVSS) of $2300 \mathrm{mg} / \mathrm{L}$ and a sludge volume index $\left(\mathrm{SVI}_{30}\right)$ of $125 \mathrm{~mL} / \mathrm{g}$, respectively.

\subsection{Petroleum refinery wastewater (PRW)}

The PRW was prepared by dissolving oil obtained from a vacuum distillation unit into tap water using a homogenizer mixer (Mark II Model 2.5, Primix Corporation, Japan), mainly consisted of alkanes, aromatic compounds, phenols, alcohols, esters, organic acids and heterocyclic compounds. The PRW provided the sole carbon sources during the investigation. $\mathrm{NH}_{4} \mathrm{Cl}$ and $\mathrm{KH}_{2} \mathrm{PO}_{4}$ were added to maintain the ratios of chemical oxygen demand (COD): $\mathrm{NH}_{4}{ }^{+}-\mathrm{N}$ : $\mathrm{P}$ around 100: 3-8: 1, and $\mathrm{NaHCO}_{3}$ was used to keep the $\mathrm{pH}$ in the range of 7.0-8.0. Trace elements were added into the PRW which was prepared according to Chen et al. (2019).

\subsection{Reactor configuration and operation}

Two identical SBR reactors (R0, control; Rw, added with biochar-WPS) were employed, with a working volume of $2 \mathrm{~L}(7.0 \mathrm{~cm}$ of internal diameter and $58.2 \mathrm{~cm}$ of height). Biochar-WPS was added into Rw with a concentration of $3 \%$ (v/v) (Chen et al. 2018). Air was supplied with an air pump (YTZ-312, Shandong, China) through the diffusers located in the reactor bottom (Fig. 1a), and the dissolved oxygen (DO) concentration was kept at $6.5-8.5 \mathrm{mg} / \mathrm{L}$. The influent and effluent were controlled by two peristaltic pumps (BT300-2J, Baoding, China), with a volumetric exchange ratio of $50 \%$. The overall system was controlled by a time controller (KWD-T02, Zhejiang, China).

The experimental period consisted of four phases: start-up and acclimation (days 1-42), load shocking 
(a) Time controller
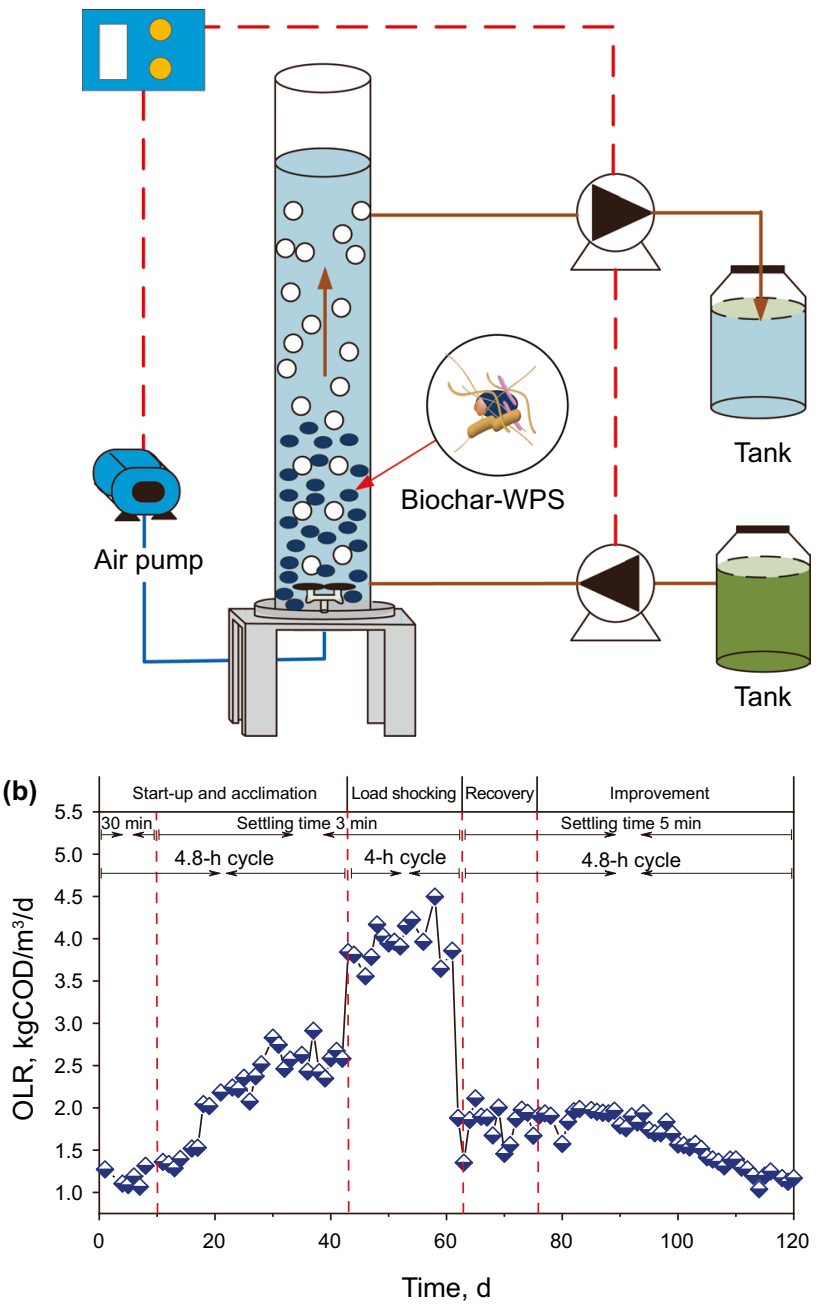

Fig. 1 a Configuration of the sequencing batch reactor and $\mathbf{b}$ organic loading rate over the operational period

(days 43-62), recovery (day 63-76) and improvement (days 77-120). The operational conditions are shown in Fig. 1b. In the first phase, the influent oil concentration increased from 127.07 to $298.93 \mathrm{mg} / \mathrm{L}$ while the settling time decreased from $30 \mathrm{~min}$ (days 1-9) to $5 \mathrm{~min}$ (days 10-15 day) and to $3 \mathrm{~min}$ (days 16-42). The reactors were operated with a cycle of $4.8 \mathrm{~h}$ for the first period. During the load shocking phase, a 4-h cycle was used instead of the 4.8-h cycle, and the organic loading rate (OLR) increased to $3.40-4.50 \mathrm{~kg}$ COD $\left(\mathrm{m}^{3} / \text { days }\right)^{-1}$. In the recovery phase, the 4.8 -h cycle was reapplied again, and the settling time increased from $3 \mathrm{~min}$ (days 43-62) to $5 \mathrm{~min}$ over days 63-120. To improve denitrification within the system, an anoxic period was introduced, using an operational mode of alternate aeration/non-aeration in the fourth period. Further detailed operational conditions are shown in Table 1.

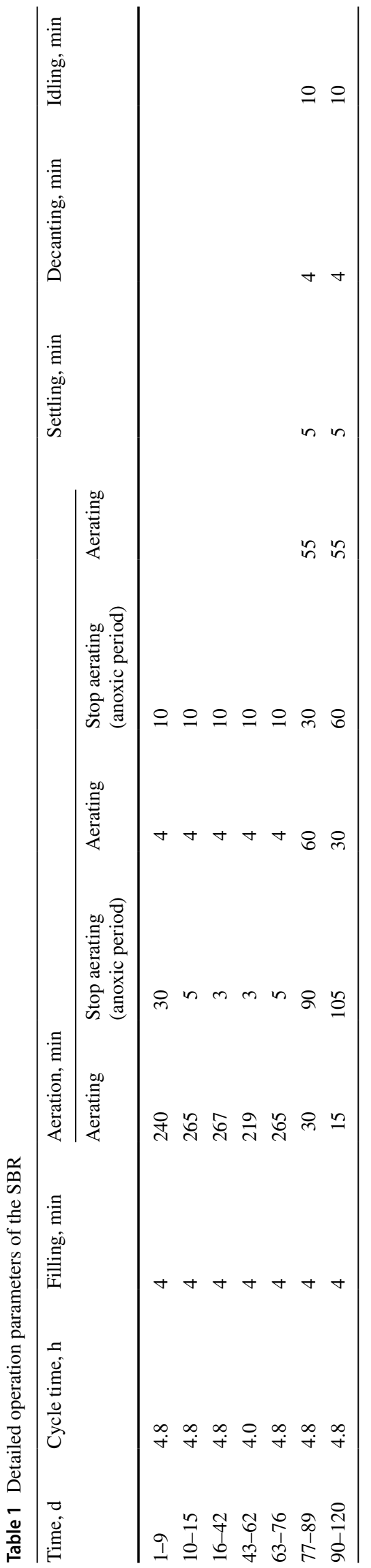




\subsection{Analytical methods}

COD and $\mathrm{NH}_{4}{ }^{+}-\mathrm{N}$ were analyzed according to standard methods (APHA 2005). Total nitrogen (TN) was measured by a total organic carbon analyzer (TOC-LCPH, Shimadzu Corporation, Japan) equipped with a TN measuring detector. $\mathrm{pH}$ was detected using a pH meter (Mettler Toledo FE28, Switzerland). Oil concentrations in the influent and effluent were measured using an infrared oil meter (OIL 480, China). Particle size of AGS was investigated according to Laguna and Ouattara (1999).

Protein and polysaccharide were extracted using the methods described by Chen et al. (2019). Protein was determined according to the Bradford method (Bradford 1976) with bovine serum albumin as the standard. Polysaccharide content was measured according to Dubois et al. (1956) with glucose as the standard. The sum of protein and polysaccharide was considered as extracellular polymeric substance (EPS).

The surface areas and porosity of biochar were determined using a specific surface and aperture analyzer (ASAP 2020M, USA). The surface morphology and element composition of biochar were determined using a scanning electron microscope (SEM) (Quanta 200F, Netherlands), equipped with an energy-dispersive X-ray analyzer (FEI, Hillsboro, OR, USA). Element contents ( $\mathrm{C}, \mathrm{H}, \mathrm{O}$ and $\mathrm{N})$ of biochar were determined using an elemental analyzer (Vario EL, Elementar Analysen System GambH, Germany). The surface functional groups on the biochar were determined using a FT-IR spectrometer (MAGNA-IR 560 ESP, USA).

\subsection{Microbial community analysis}

The seed sludge (SS) and aerobic granules of R0 and Rw (A0, Aw) on day 120 were collected and sent to Majorbio Company (Shanghai, China). The genomic DNA was extracted and sequenced using an Illumina MiSieq platform in Majorbio Company. The V4 region of 16S rDNA gene was PCR amplified using the 515FmodF (5'-GTGYCA GCMGCCGCGGTAA-3') and 806RmodR (5'-GGACTA CNVGGGTWTCTAAT- $3^{\prime}$ ) primer pair. The PCR mixture components and amplification parameters were similar to those of Ming et al. (2020). Microbial community structure and diversity were analyzed on the free online platform of Majorbio I-Sanger Cloud Platform (www.i-sanger.com).

\section{Results and discussion}

\subsection{Characterization of biochar}

The physiochemical properties of biochar-WPS were determined in order to evaluate its application potential in facilitating aerobic granulation during treatment of PRW. The SEM image revealed that the biochars had a rough and irregular surface area and a highly developed porous structure (Fig. 2a). The surface area $\left(229.77 \mathrm{~m}^{2} / \mathrm{g}\right)$ and pore volume $\left(0.28 \mathrm{~cm}^{3} / \mathrm{g}\right)$ (Table 2) were found to be significantly higher than other biochars produced from both municipal sewage sludge and wastewater sludge from coking (Chen et al. 2014a; Zhang et al. 2018a). This observed difference mostly arises from the higher oil content of the waste petroleum activated sludge, which is volatilized at high temperatures, resulting in increased porosity. The porous structure accumulated organic substances, reducing the toxicity of PRW and increasing bacterial survival. As determined by EDX analysis, biochar-WPS was mostly composed of C, $\mathrm{O}, \mathrm{Si}$, and certain metals (Fig. 2a). Metals including Mg, $\mathrm{Al}, \mathrm{Ca}, \mathrm{Fe}$ and $\mathrm{Zn}$ were observed on the biochar surface. The presence of $\mathrm{Mg}, \mathrm{Ca}$ and $\mathrm{Fe}$ could possibly stimulate EPS production which is beneficial for microbial surface attachment and would accelerate aerobic granulation (Sajjad and Kim 2015; Ren et al. 2018). Certain minerals and elements within biochar could also serve as nutrient sources and enhance microbial activity and biodegradation of available organic contaminants (Yuan et al. 2013; Ogbonnaya and Semple 2013).

The H/C atomic ratio (0.42) (Table 2) of biochar-WPS indicated a relatively high degree of carbonization and aromaticity, ensuring that polycyclic aromatic hydrocarbons strongly adsorbed through interactions with $\pi$-electrons (Zhang et al. 2018a; Kubicki 2006). The relatively high $\mathrm{O} / \mathrm{C}$ and $(\mathrm{O}+\mathrm{N}) / \mathrm{C}$ atomic ratios of biochar-WPS $(0.21$ and $0.27)$ suggested a higher degree of surface hydrophilicity and more polar groups (Zielinska et al. 2015). This is beneficial for microbial adhesion and pollutant removal (Zhang et al. 2018a). The biochar-WPS also had a much higher $\mathrm{C}$ and $\mathrm{N}$ content $(38.23 \% \mathrm{C}$ and $2.76 \% \mathrm{~N})$ when compared with comparable biochars derived from coking wastewater treatment sludge $(18.09 \% \mathrm{C}$ and $0.97 \% \mathrm{~N})$ and municipal sewage sludge $(16.92 \pm 0.55 \% \mathrm{C}, 0.95 \% \pm 0.07 \mathrm{~N})$ (Zhang et al. 2018a; Chen et al. 2014a).

FTIR spectroscopy of biochar-WPS is shown in Fig. 2b, indicating the existence of functional groups on the surface of biochar-WPS. The peak at $3450 \mathrm{~cm}^{-1}$ is strong and broad, which could be the hydroxyl groups originated from alcohols or carboxylic groups (Chen et al. 2015; Zhang et al. 2011a). The weak peak at $2918 \mathrm{~cm}^{-1}$ is attributable to the stretching of $\mathrm{C}-\mathrm{H}$ bonds of aliphatic compounds. The peak intensity at wave numbers $1611 \mathrm{~cm}^{-1}$ and $1377 \mathrm{~cm}^{-1}$ corresponds to the stretching of $\mathrm{C}=\mathrm{C}$ and $\mathrm{C}=\mathrm{O}$ bonds in aromatic ring (Shen et al. 2019; Zhang et al. 2018a). The peak intensity at wave numbers of $1062 \mathrm{~cm}^{-1}, 795 \mathrm{~cm}^{-1}$, and $472 \mathrm{~cm}^{-1}$ results from the vibration absorption of $\mathrm{Si}-\mathrm{O}-\mathrm{Si}$ (Shi et al. 2019). The functional groups of $\mathrm{C}=\mathrm{O}$ on the biochar surface possesses the abilities of pollutant adsorption improvement and electrons supplement 
(a)
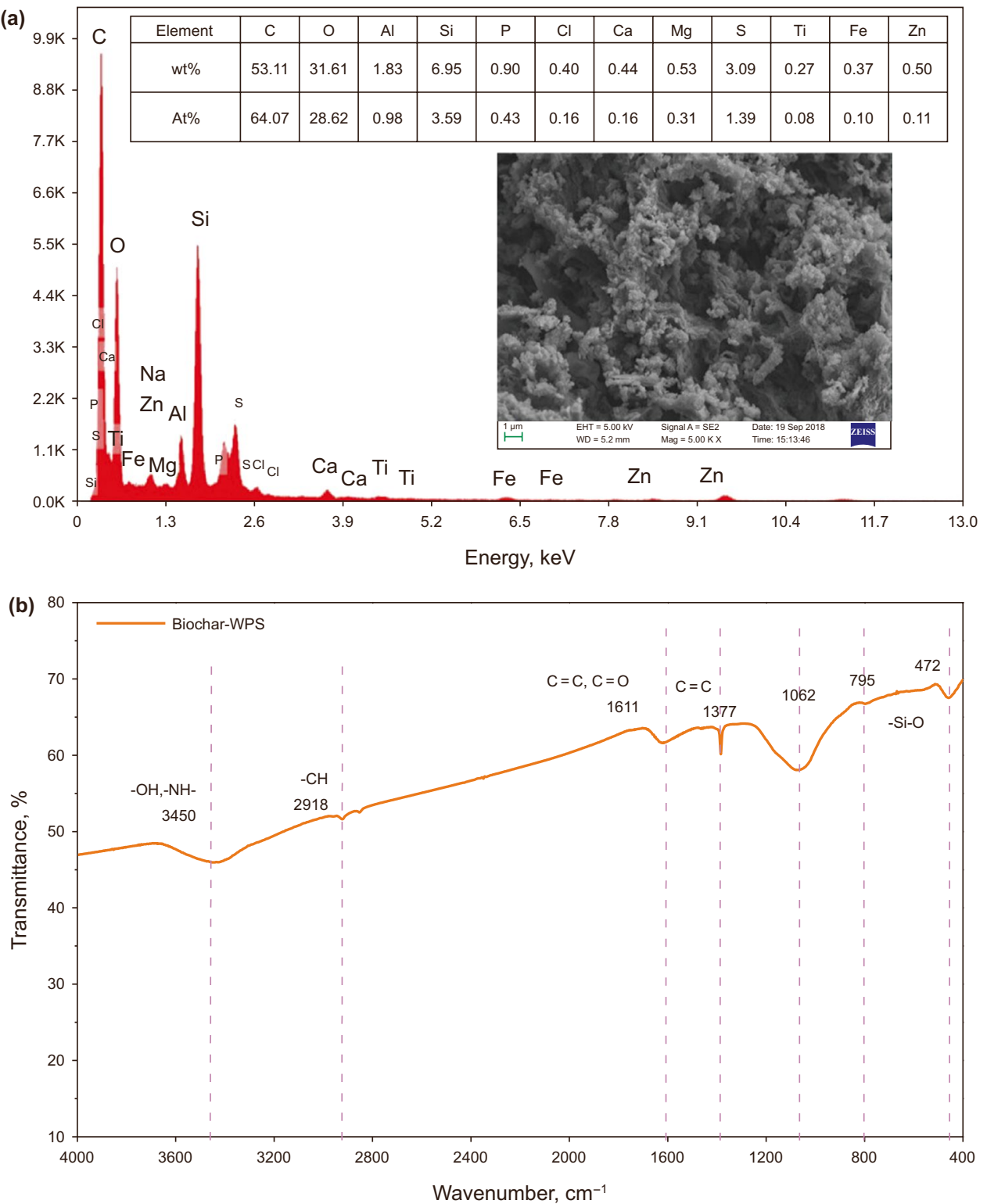

Fig. 2 a EDX and SEM images and b FTIR spectrums of biochar-WPS

Table 2 BET and elemental analysis of biochar

\begin{tabular}{lllr}
\hline BET analysis & & \multicolumn{2}{l}{ Elemental analysis } \\
\hline \multirow{3}{*}{ Surface area, $\mathrm{m}^{2} / \mathrm{g}$} & 229.77 & $\mathrm{C} \%$ & 38.23 \\
Pore diameter, $\mathrm{nm}$ & 4.84 & $\mathrm{O} \%$ & 1.34 \\
& & $\mathrm{~N} \%$ & 10.82 \\
Total pore volume, $\mathrm{cm}^{3} / \mathrm{g}$ & \multirow{2}{*}{0.28} & $\mathrm{H} / \mathrm{C}$ & 2.76 \\
& & $\mathrm{O} / \mathrm{C}$ & 0.42 \\
& & $(\mathrm{O}+\mathrm{N}) / \mathrm{C}$ & 0.21 \\
& & & 0.27 \\
\hline
\end{tabular}

for the generation of reactive oxygen species $\left(\mathrm{O}_{2} \cdot{ }^{\mathrm{L}} \mathrm{SEP}\right)$ further accelerating degradation of organic compounds (Zhang et al. 2018a). In addition, biochar can function as a source and sink for the movement of electrons to and from the environment, promoting direct interspecies electron transfer and accelerating the pollutants biodegradation (Chen et al. 2014b).

\subsection{Performances of reactors}

\subsubsection{The impact of biochar-WPS on organic compound removal}

The influent COD concentration ranged between 430 and $1500 \mathrm{mg} / \mathrm{L}$ (Fig. 3a). The accompanying OLR ranged 

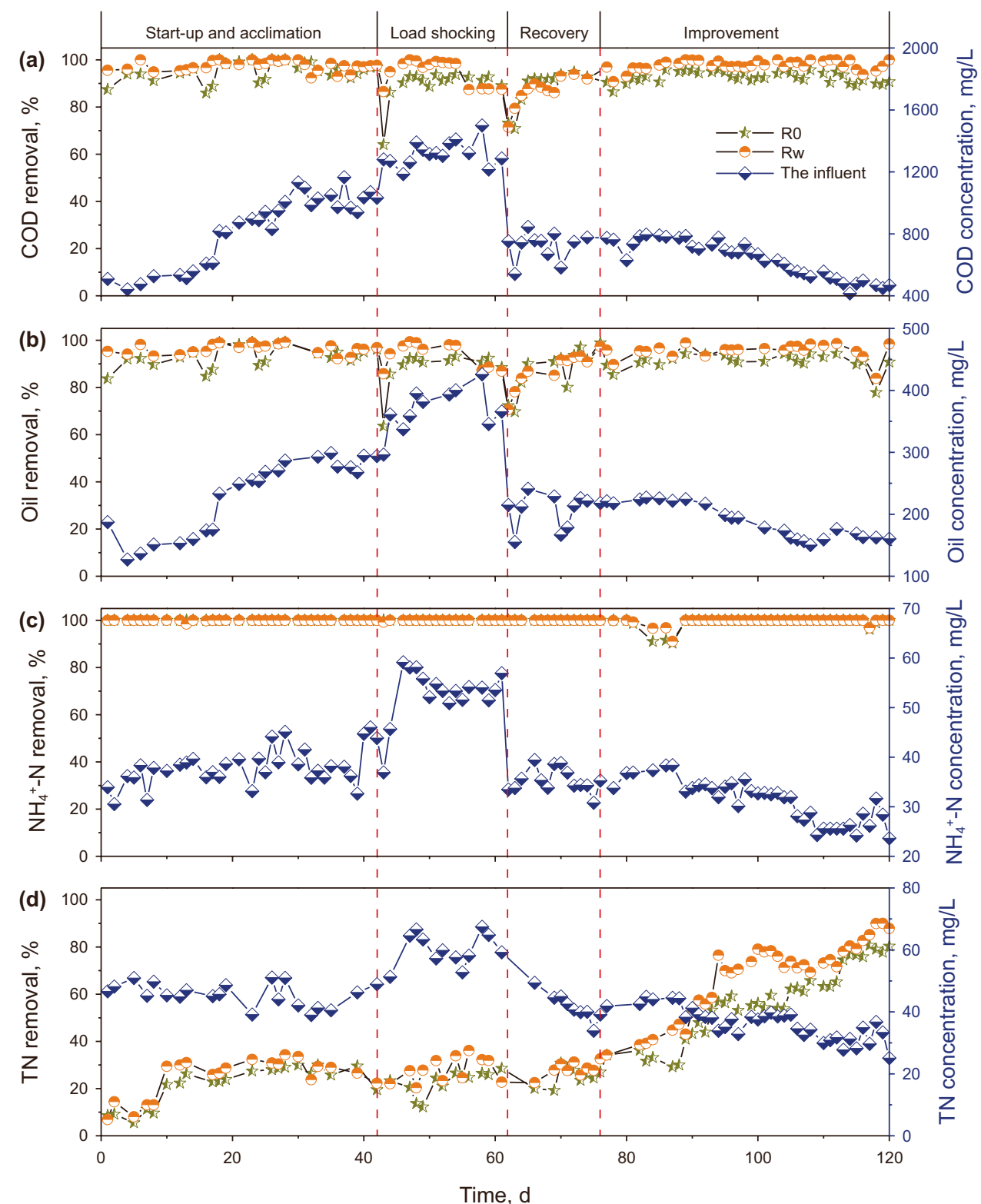

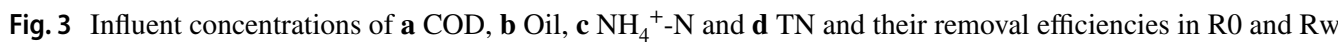

between $1.1 \mathrm{~kg} \operatorname{COD}\left(\mathrm{m}^{3} \text { days }\right)^{-1}$ and $4.5 \mathrm{~kg} \operatorname{COD}\left(\mathrm{m}^{3}\right.$ days $)^{-1}$ (Fig. 3b). Except for the period of loading shock, the rates of COD removal were stable in both R0 $(92.84 \%)$ and $\mathrm{Rw}(95.73 \%)$. A decreased settling time (5 $\mathrm{min}$ to $3 \mathrm{~min}$ ) temporarily reduced COD removal rates in the R0 reactor during the start-up and acclimation period. On day 43 , an increase for OLR to $3.8 \mathrm{~kg}$ COD $\left(\mathrm{m}^{3} \text { days }\right)^{-1}$ decreased the COD removal efficiency in R0 (64.08\%), which required 3 days to recover $(90.26 \%)$. COD removal efficiency was also reduced to a much lesser degree $(86.52 \%)$ in the Rw reactor and rapidly recovered (94.91\%) in 1 day. Increasing the OLR [4.50 $\mathrm{kg} \operatorname{COD}\left(\mathrm{m}^{3} \text { days }\right)^{-1}$ ] and influent COD (1500 mg/L) (Fig. 1b) resulted in a decline in COD removal for both $\mathrm{R} 0(70.83 \%)$ and $\mathrm{Rw}$ (71.47\%). During the recovery period, the OLR reduced to below $2.0 \mathrm{~kg} \operatorname{COD}\left(\mathrm{m}^{3} \text { days }\right)^{-1}$, and the settling time increased to $5 \mathrm{~min}$. Both $\mathrm{R} 0$ and $\mathrm{Rw}$ recovered their COD removal efficiencies up to $90 \%$. The effects on COD removal for both R0 (93.09\%) and Rw (97.44\%) were negligible exposed to transient anoxic conditions. The corresponding effluent COD concentrations were $43.48 \mathrm{mg} / \mathrm{L}$ (R0) and $16.76 \mathrm{mg} / \mathrm{L}$ (Rw).

A similar tendency was observed during oil removal as the COD in the influent was supplied entirely by the PRW (Fig. 3b). Average oil removal efficiency was $89.40 \%$ in R0 and $93.36 \%$ in Rw, respectively. 
The biochar-WPS addition improved the COD and oil removal efficiencies as well as the capability of shock loading resistant. Such enhanced performance was also reported by Zhang et al. (2017) who showed that the removal efficiency of total organic carbon improved $6.28 \%$ using rice husk-biochars. The porous structure and rough surfaces of biochar could provide a favorable microenvironment for microbial community from adverse surroundings. Biochar could enrich bacterial abundance and enhance the aromatics biodegradation (Kong et al. 2018; Qin et al. 2013). In addition, oxygen-containing groups [e.g., hydroxyl (O-H) and carbonyl $(\mathrm{C}=\mathrm{O})$ groups] on biochar surfaces can act as reactive sites, that are also beneficial for pollutant degradation (Zhang et al. 2018a).

\subsubsection{The impact of biochar-WPS on nitrogen removal}

The two reactors efficiently removed $\mathrm{NH}_{4}{ }^{+}-\mathrm{N}(100 \%)$ over the operational period, although a fluctuation was observed during the anoxic exposure (Fig. 3c). In contrast, TN removal efficiencies were low. R0 and Rw only removed $23 \%$ and $30 \%$ of the TN, respectively, over the first 76 days of operation (Fig. 3d). To determine the reason for the unfavorable denitrification results, DO and COD concentrations were determined over a typical SBR cycle on the 75th day. The DO content was found to be high $(6.5 \mathrm{mg} / \mathrm{L})$ in both reactors. The COD concentration dropped rapidly within $44 \mathrm{~min}$, and over $90 \%$ of the COD was removed by $144 \mathrm{~min}$. This suggests that both anoxic conditions and the carbon sources inhibited denitrification. To enhance the TN removal efficiency, anoxia (120 min without aeration) was introduced on the 77th day (Table 1). This improved TN removal in both R0 (40\%) and Rw (50\%). After the 90th day, the anoxic period was further increased (165 min) and enhanced the performance of the two reactors by an additional 20\%. Furthermore, when the OLR was further decreased to $1.1 \mathrm{~kg}$ $\operatorname{COD}\left(\mathrm{m}^{3} \text { days }\right)^{-1}$ during the last 11 days of operation, the TN removal efficiencies increased to $80 \%$ (R0) and $90 \%$ (Rw). The effluent TN concentrations were $7.76 \mathrm{mg} / \mathrm{L}$ in $\mathrm{R} 0$ and $5.54 \mathrm{mg} / \mathrm{L}$ in $\mathrm{Rw}$ on an average.

Alkanes, olefins, arenes and heterocyclic nitrogen compounds in PRW can inhibit both nitrifying and denitrifying bacteria (Zhang et al. 2010). The addition of biochar improved TN removal efficiencies, which could be attributed to shelter and provision of an anoxic environment for the denitrifying bacteria.

\subsubsection{The impact of biochar-WPS on sludge granulation}

Seed sludge morphology was loose, irregularly shaped and black in color with particle diameters less than $0.076 \mathrm{~mm}$. Small granules were visibly observed in Rw on the 4th day, but only minimally in R0 on the 8th day. A short settling time is a prerequisite for facilitating granulation, including the development of microbiological and physiological changes which further accelerate microbial aggregation (Xiong and Liu 2012). As the settling times decreased (from 30 to $5 \mathrm{~min}$ ), the sludge size increased gradually. After 15 days of operation, $65.55 \%$ of the sludge in Rw had diameters larger than $0.46 \mathrm{~mm}$, compared with $33.82 \%$ in R0 (Fig. 4). On the 16th day, the settling time decreased from 5 to $3 \mathrm{~min}$ and greater numbers of granules were observed in both reactors. The granular sludge larger than $0.46 \mathrm{~mm}$ accounted for $53.8 \%$ of total granules in $\mathrm{R} 0$ and $79.6 \%$ in Rw on day 30. Successful aerobic granulation is achieved when $50 \%$ of the total sludge possesses particle sizes $>0.34 \mathrm{~mm}$ (Bhunia and Ghangrekar 2006). Aerobic sludge granulation was accomplished within 15 days in Rw and 30 days in R0, respectively. Granules less than $0.25 \mathrm{~mm}$ in diameter were consistently observed in R0 but not in Rw. Particles larger than $2 \mathrm{~mm}$ in diameter were only formed in Rw. The inhibitory effect of a complex influent on granular growth has also been observed in other studies (Zhang et al. 2011b; Chen et al. 2019). At the end of operation (day 120), granules $(>0.46 \mathrm{~mm})$ in Rw accounted for $82.5 \%$ of the total which was $20 \%$ higher than that in R0.

The concentration of EPS in the sludge was determined (Fig. S1). EPS content significantly increased during aerobic granulation and reached a maximum for $\mathrm{Rw}[61.66 \mathrm{mg} /$ ( $\mathrm{g} \cdot \mathrm{VSS})]$ on day 15 , whereas the maximum concentration for R0 [51.12 mg/(g.VSS)] was observed on day 30. These

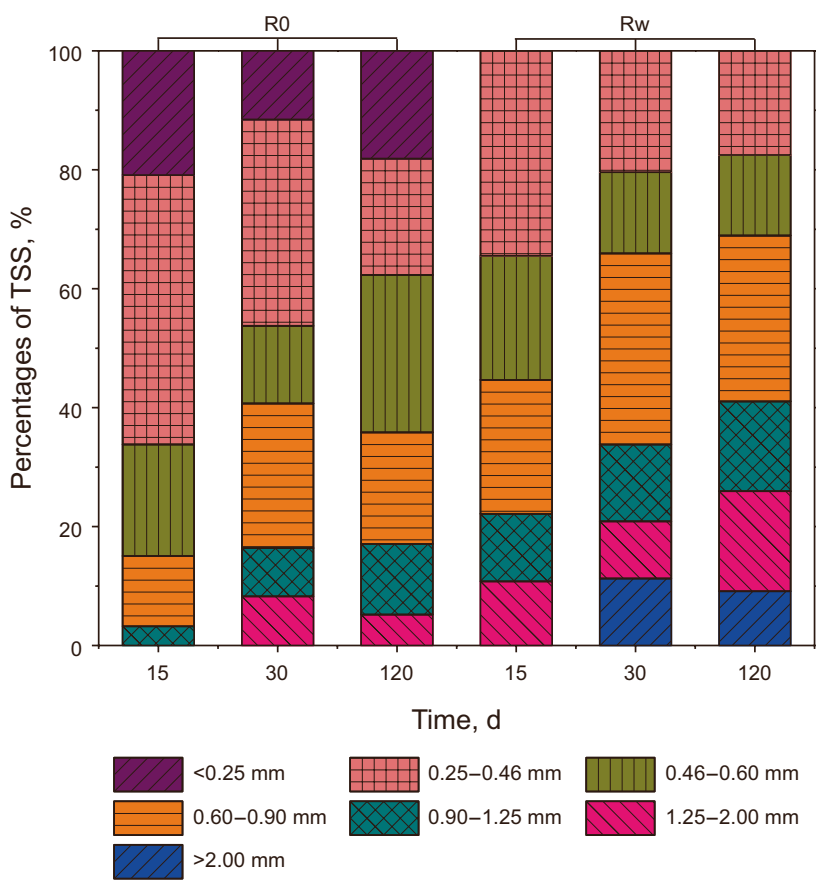

Fig. 4 Size distribution (by weight) of the granules in R0 and Rw collected on day 15,30 and 120 
Table 3 Results of alpha diversity analysis

\begin{tabular}{lllll}
\hline Sample & Sources & Shannon & Chao & Coverage \\
\hline SS & Seed sludge & 4.88 & 587.65 & 0.99 \\
A0 & R0 & 3.57 & 470.50 & 0.99 \\
Aw & Rw & 3.69 & 493.55 & 0.99 \\
\hline
\end{tabular}

results coincided with the observed granulation. It had been reported that EPS secretion occurs mostly aerobically and has a vital role in microbial aggregation, granular formation and structural stability (Nancharaiah and Reddy 2018).

\subsubsection{The impact of biochar-WPS on microbial community}

The richness and diversity of the microbial communities of seed sludge (SS) and AGS sampled in R0 and Rw (A0, Aw) on day 120 are represented by alpha diversity shown in Table 3. A total of 137,492 sequences having an average length of $273.06 \mathrm{bp}$ were obtained. The coverage was higher than $99 \%$ indicated an adequate sequencing depth was performed.

Compared to granular sludge, the inoculum possessed a greater richness and diversity as indicated by the Chao index and the Shannon index. Decreased richness and diversity were due to the re-acclimation of the biological communities after exposure to the PRW. The Chao and Shannon indices of Aw were significantly higher when compared with A0, indicating that the addition of biochar-WPS was beneficial for community establishment. The biochar affects solution chemical activity and the ecotoxicity of organic compounds and also provide a favorable microenvironment (Ogbonnaya and Semple 2013).

The dominant phylum in the seed sludge was proteobacteria $(40.0 \%)$, followed by planctomycetes $(11.0 \%)$, thaumarchaeota (10.6\%) and actinobacteria (7.5\%) (Fig. 5a). After a long-term operation within PRW, the microbial community changed. The most abundant phyla in A0 and Aw were proteobacteria (78.1\% and $73.0 \%)$ and actinobacteria (14.2\% and $10.7 \%$ ), which increased significantly compared to the seed sludge. Many proteobacteria and actinobacteria are implicated with the degradation of petroleum hydrocarbons (Liu et al. 2017b). Furthermore, many proteobacteria are known to secrete EPS, which could accelerate the adhesion of flocculent sludge (Liu et al. 2017a).

At the genus level, A0 and Aw had similar microbial compositions but that were significantly different from the seed sludge (Fig. 5b). The dominant genera in the seed sludge were uncultured archaeon clone HSZ-A-2 (14.5\%), uncultured delta proteobacterium (11.7\%), uncultured bacterium clone $48 b$ (7.1\%) and Herminiimonas (3.5\%), which were not present in $\mathrm{A} 0$ and Aw. Uncultured gamma proteobacterium $(36.6 \%$ and $39.0 \%)$, mycobacterium
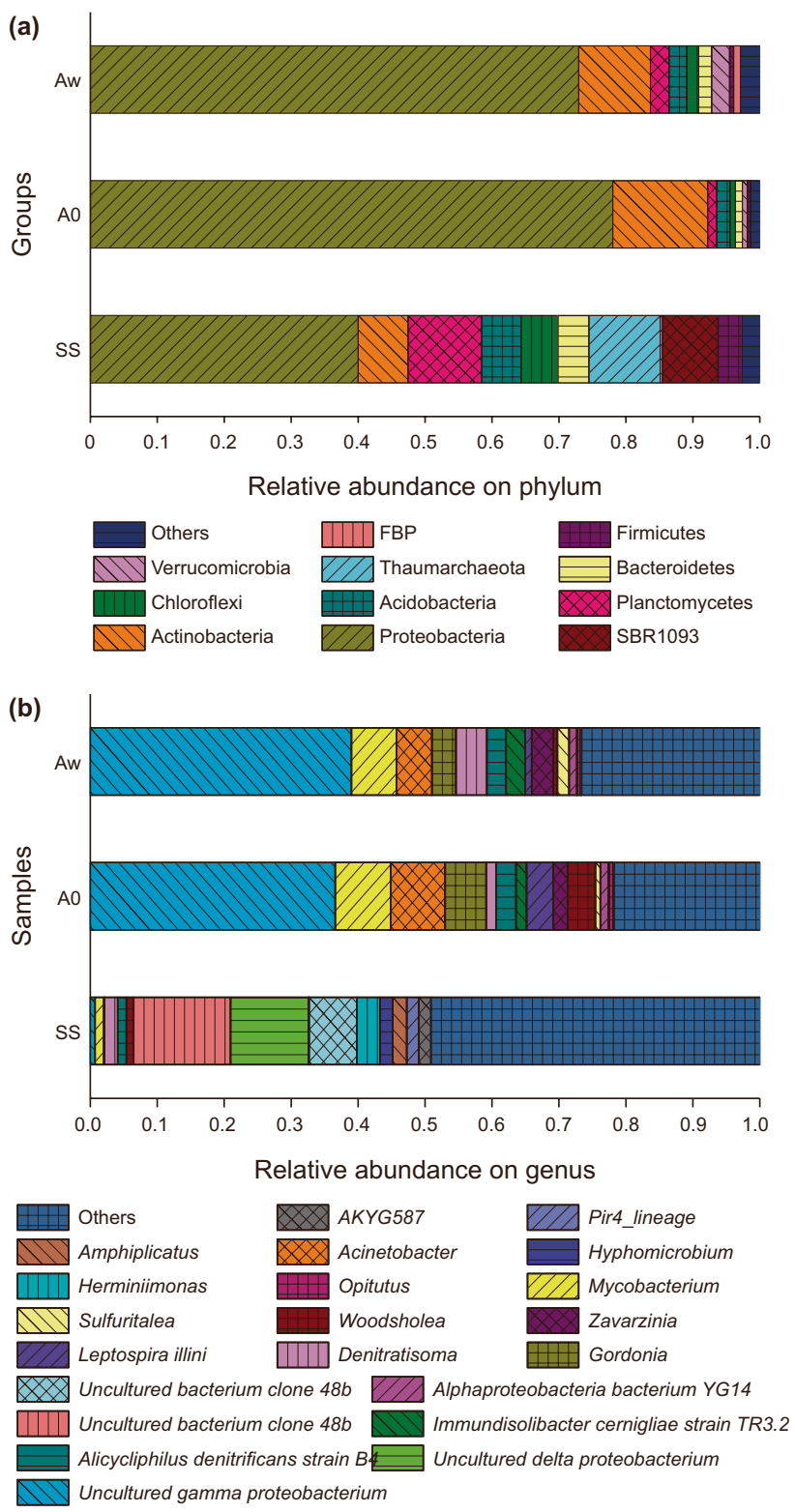

Fig. 5 Microbial communities of seed sludge and granules in R0 and Rw on day 120 (SS: seed sludge; A0: granules collected from R0; Aw: granules collected from Rw)

$(8.3 \%$ and $6.7 \%)$ and acinetobacter $(8.1 \%$ and $5.3 \%)$ were the most abundant genera in A0 and Aw, known to be capable of degrading oil (Militon et al. 2010; Yang et al. 2015). These results indicated the successful enrichment of microorganisms with the ability to degrade petroleum during the treatment of PRW. In addition, Denitratisoma and Sulfuritalea, that are related to denitrifiers, were more abundant in Aw (4.6\% and $1.5 \%)$ than A0 (1.8\% and $0.7 \%$ ), which may be the reason for better TN removal in Rw (Du et al. 2017). In conclusion, biochar-WPS addition had less effect on microbial community composition. 


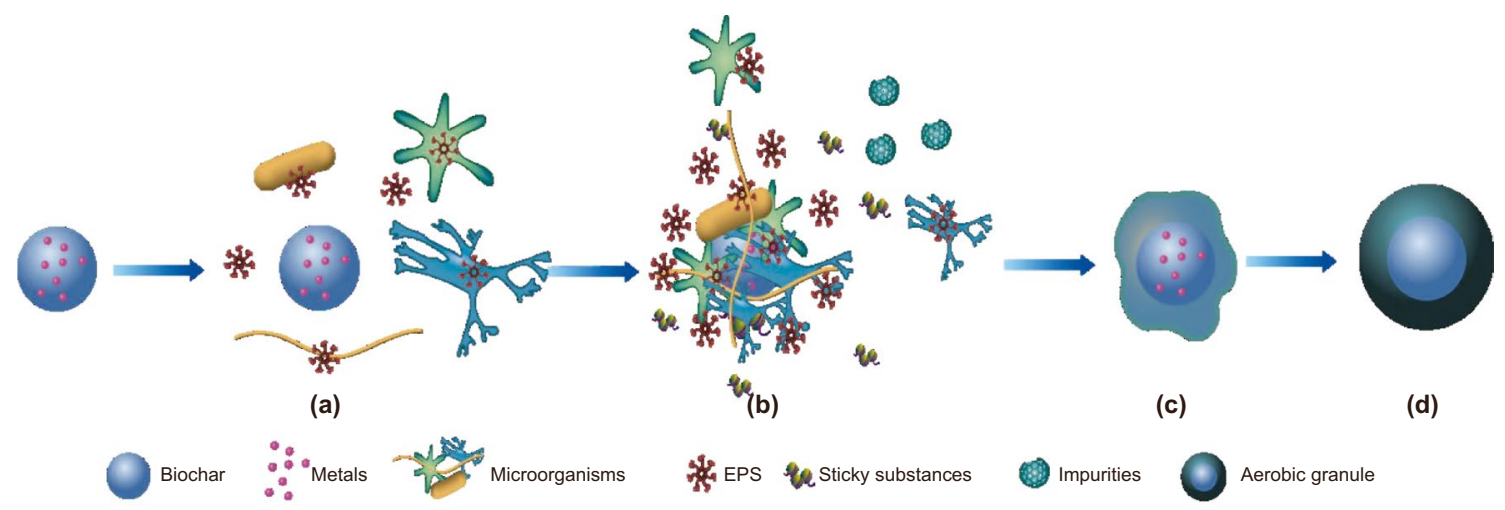

Fig. 6 Proposed mechanism for biochar-WPS-meditated aerobic granule formation. a Biochar with microorganisms; $\mathbf{b}$ microorganisms adhered to biochars, more EPS were secreted against adverse conditions; EPS and sticky substances in oil bind and bridge with microorganisms; $\mathbf{c}$ initial formation of granular sludge; $\mathbf{d}$ collisions and friction provided by hydraulic shearing force and particles helped to shape the granules, and mature aerobic granules were formed

\subsubsection{Mechanism of rapid aerobic granulation with biochar-WPS}

Biochar-WPS has abundant pores and a correspondingly high surface area, which can contribute to initial successful adhesion of microorganisms. The porous structure further shelters microaggregates from adverse environmental conditions during the early stages of granule development. Cationic metal ions located on the surface of biochar accelerated microbial adhesion through interactions with negatively charged cellular components and can promote EPS secretion (Adav et al. 2008; Nancharaiah and Reddy 2018). EPS secreted by the microorganisms shorten granule formation time by functioning as bridges between bacteria, metal species and other particles (Liu et al. 2004; Adav et al. 2008).

A possible mechanism for biochar-WPS mediated aerobic granulation is presented in Fig. 6. The microorganisms first adhere and aggregate with biochar-WPS due to its physicochemical properties. The toxicity of PRW, external hydraulic shear forces and metals present on the surfaces of biochar-WPS facilitate EPS production, forming bridges between bacterial cells and other particulates (Nancharaiah and Reddy 2018). The EPS accumulated around bacterial cells could modify the physico-chemical characteristics of the cellular surface components, such as charge and hydrophobicity, further increasing microbial aggregation (Adav et al. 2008; Liu et al. 2004; Nancharaiah and Reddy 2018). In addition, the sticky substances (such as asphaltenes) in oil also bind and bridge with the microorganisms. Finally, aggregates gradually increase in size and become the precursors for aerobic granule formation. Physical friction induced by hydraulic shear forces contributes to shape the smooth granular sludge and mature granular sludge is finally formed (Adav et al. 2008; Nancharaiah and Reddy 2018).

\section{Conclusions}

Biochar prepared with waste petroleum activated sludge possessed a porous structure with high surface area and having abundant metals and functional chemical groups. Such properties enabled rapid aerobic granular formation and facilitated the biodegradation of organic compounds. The presence of biochar-WPS enlarged granule sizes, improved reactor performance and resistance to OLR shock loading. In addition, favorable microbial communities developed along with an increased abundance of petroleum degraders and denitrifiers. These results suggested biochar-WPS can provide an efficient, eco-friendly and cost-effective way for rapid granulation in SBR for the treatment of PRW.

Acknowledgements This study was supported in part by the Science Foundation of China University of Petroleum-Beijing, China (No. 2462018BJB001 and 2462020XKJS04), the National Natural Science Foundation of China, China (No. 21776307), and the Independent Project Program of State Key Laboratory of Petroleum Pollution Control, China (Grant No. PPCIP2017004).

Open Access This article is licensed under a Creative Commons Attribution 4.0 International License, which permits use, sharing, adaptation, distribution and reproduction in any medium or format, as long as you give appropriate credit to the original author(s) and the source, provide a link to the Creative Commons licence, and indicate if changes were made. The images or other third party material in this article are included in the article's Creative Commons licence, unless indicated otherwise in a credit line to the material. If material is not included in the article's Creative Commons licence and your intended use is not permitted by statutory regulation or exceeds the permitted use, you will need to obtain permission directly from the copyright holder. To view a copy of this licence, visit http://creativecommons.org/licenses/by/4.0/. 


\section{References}

Adav SS, Lee DJ, Show KY, Tay JH. Aerobic granular sludge: recent advances. Biotechnol Adv. 2008;26(5):411-23. https://doi. org/10.1016/j.biotechadv.2008.05.002.

APHA. Standard methods for the examination of water and wastewater. twentieth ed. Washington: American Public Health Association; 2005.

Bhunia P, Ghangrekar MM. Comments on "Enhanced granulation by natural ionic polymer additives in UASB reactor treating low-strength wastewater", a full paper published in Water Res. 2005;39(16):3801-810 by Manoj K. Tiwari, Saumyen Guha, C. S. Harendranath, and Shweta. Water Res. 2006;40(7):1505-1506. https://doi.org/10.1016/j.watres.2006.01.033.

Bradford MM. A rapid and sensitive method for quantification of microgram quantities of protein utilizing principle of proteindye binding. Anal Biochem. 1976;72:248-54. https://doi. org/10.1016/0003-2697(76)90527-3.

Cetin E, Karakas E, Dulekgurgen E, Ovez S, Kolukirik M, Yilmaz G. Effects of high-concentration influent suspended solids on aerobic granulation in pilot-scale sequencing batch reactors treating real domestic wastewater. Water Res. 2018;131:74-89. https://doi. org/10.1016/j.watres.2017.12.014.

Chen C, Ming J, Yoza BA, Liang J, Li QX, Guo H, et al. Characterization of aerobic granular sludge used for the treatment of petroleum wastewater. Bioresour Technol. 2019;271:353-9. https://doi. org/10.1016/j.biortech.2018.09.132.

Chen C, Yao X, Li QX, Wang Q, Liang J, Zhang S, et al. Turf soil enhances treatment efficiency and performance of phenolic wastewater in an up-flow anaerobic sludge blanket reactor. Chemosphere. 2018;204:227-34. https://doi.org/10.1016/j.chemospher e.2018.04.040.

Chen J, Mu L, Jiang B, Yin H, Song X, Li A. TG/DSC-FTIR and Py-GC investigation on pyrolysis characteristics of petrochemical wastewater sludge. Bioresour Technol. 2015;192:1-10. https://doi. org/10.1016/j.biortech.2015.05.031.

Chen SS, Rotaru AE, Shrestha PM, Malvankar NS, Liu FH, Fan W, et al.. Promoting interspecies electron transfer with biochar. Sci Rep. 2014a;4:5019. https://doi.org/10.1038/srep05019.

Chen T, Zhang Y, Wang H, Lu W, Zhou Z, Zhang Y, et al. Influence of pyrolysis temperature on characteristics and heavy metal adsorptive performance of biochar derived from municipal sewage sludge. Bioresour Technol. 2014b;164:47-544. https://doi. org/10.1016/j.biortech.2014.04.048.

Dai YJ, Zhang NX, Xing CM. The adsorption, regeneration and engineering applications of biochar for removal organic pollutants: a review. Chemosphere. 2018;223:12-27. https://doi.org/10.1016/j. chemosphere.2019.01.161.

Dubois M, Gilles KA, Hamilton JK, Rebers PA, Smith F. Colorimetric method for the determination of sugars and other related substances. Anal Chem. 1956;28:330-56. https://doi.org/10.1021/ ac60111a017.

Du R, Cao SB, Li BK, Niu M, Wang SY, Peng YZ. Performance and microbial community analysis of a novel DEAMOX based on partial-denitrification and anammox treating ammonia and nitrate wastewaters. Water Res. 2017;108:46-56. https://doi. org/10.1016/j.watres.2016.10.051.

Gobi K, Mashitah MD, Vadivelu VM. Development and utilization of aerobic granules for the palm oil mill (POM) wastewater treatment. Chem Eng J. 2011;174(1):213-20. https://doi.org/10.1016/j. cej.2011.09.002.

Kaiser MJ. A review of refinery complexity applications. Pet Sci. 2017;14(1):167-94. https://doi.org/10.1007/s12182-016-0137-y.

Kong LL, Gao YY, Zhou QX, Zhao XY, Sun ZW. Biochar accelerates PAHs biodegradation in petroleum-polluted soil by biostimulation strategy. J Hazard Mater. 2018;343:276-84. https ://doi.org/10.1016/j.jhazmat.2017.09.040.

Kubicki JD. Molecular simulations of benzene and PAH interactions with soot. Environ Sci Technol. 2006;40(7):2298-303. https://doi. org/10.1021/es051083s.

Laguna A, Ouattara A, Gonzalez RO, Baron O, Fama G, El Mamouni $\mathrm{R}$, et al. A simple and low cost technique for determining the granulometry of upflow anaerobic sludge blanket reactor sludge. Water Sci Technol. 1999;40(8):1-8. https://doi.org/10.1016/ S0273-1223(99)00602-2.

Lettinga G, van Velsen AFM, Hobma SW, de Zeeuw W, Klapwijk A. Use of the upflow sludge blanket (USB) reactor concept for biological wastewater treatment, especially for anaerobic treatment. Biotechnol Bioeng. 1980;22(4):699-734. https://doi.org/10.1002/ bit.260220402.

Li AJ, Li XY, Yu HQ. Aerobic sludge granulation facilitated by activated carbon for partial nitrification treatment of ammoniarich wastewater. Chem Eng J. 2013;218:253-9. https://doi. org/10.1016/j.cej.2012.12.044.

Liang XY, Gao BY, Ni SQ. Effects of magnetic nanoparticles on aerobic granulation process. Bioresour Technol. 2017;227:44-9. https ://doi.org/10.1016/j.biortech.2016.12.038.

Li H, Dong X, da Silva EB, de Oliveira LM, Chen Y, Ma LQ. Mechanisms of metal sorption by biochars: biochar characteristics and modifications. Chemosphere. 2017;178:466-78. https://doi. org/10.1016/j.chemosphere.2017.03.072.

Liu J, Li J, Wang XD, Zhang Q, Littleton H. Rapid aerobic granulation in an SBR treating piggery wastewater by seeding sludge from a municipal WWTP. J Environ Sci. 2017a;51:332-41. https://doi. org/10.1016/j.jes.2016.06.012.

Liu Q, Tang J, Liu X, Song B, Zhen M, Ashbolt NJ. Response of microbial community and catabolic genes to simulated petroleum hydrocarbon spills in soils/sediments from different geographic locations. J Appl Microbiol. 2017b;123(4):875-85. https://doi. org/10.1111/jam.13549.

Liu YQ, Liu Y, Tay JH. The effects of extracellular polymeric substances on the formation and stability of biogranules. Appl Microbiol Biotechnol. 2004;65(2):143-8. https://doi.org/10.1007/s0025 3-004-1657-8.

Ming J, Wang QH, Yoza BA, Liang JH, Guo HQ, Li J, et al. Bioreactor performance using biochar and its effect on aerobic granulation. Bioresour Technol. 2020;300:122620. https://doi.org/10.1016/j. biortech.2019.122620.

Militon C, Boucher D, Vachelard C, Perchet G, Barra V, Troquet $\mathrm{J}$, et al. Bacterial community changes during bioremediation of aliphatic hydrocarbon-contaminated soil. FEMS Microbiol Ecol. 2010;74(3):669-81. https://doi.org/10.111 1/j.1574-6941.2010.00982.x.

Nancharaiah YV, Reddy GKK. Aerobic granular sludge technology: mechanisms of granulation and biotechnological applications. Bioresour Technol. 2018;247:1128-43. https://doi.org/10.1016/j. biortech.2017.09.131.

Ogbonnaya U, Semple KT. Impact of biochar on organic contaminants in soil: a tool for mitigating risk? Agronomy. 2013;3(2):349-75. https://doi.org/10.3390/agronomy3020349.

Pijuan M, Werner U, Yuan ZG. Reducing the startup time of aerobic granular sludge reactors through seeding floccular sludge with crushed aerobic granules. Water Res. 2011;45(16):5075-83. https ://doi.org/10.1016/j.watres.2011.07.009.

Qin G, Gong D, Fan MY. Bioremediation of petroleum-contaminated soil by biostimulation amended with biochar. Int Biodeterior Biodegrad. 2013;85(7):150-5. https://doi.org/10.1016/j.ibiod .2013.07.004.

Ren XM, Chen Y, Guo L, She ZL, Gao MC, Zhao Y, et al. The influence of $\mathrm{Fe}^{2+}, \mathrm{Fe}^{3+}$ and magnet powder $\left(\mathrm{Fe}_{3} \mathrm{O}_{4}\right)$ on aerobic granulation 
and their mechanisms. Ecotox Environ Safe. 2018;164:1-11. https ://doi.org/10.1016/j.ecoenv.2018.07.072.

Rosman NH, Nor Anuar A, Othman I, Harun H, Sulong MZ, Elias SH, et al. Cultivation of aerobic granular sludge for rubber wastewater treatment. Bioresour Technol. 2013;129(2):620-3. https://doi. org/10.1016/j.biortech.2012.12.113.

Sajjad M, Kim KS. Studies on the interactions of $\mathrm{Ca}^{2+}$ and $\mathrm{Mg}^{2+}$ with EPS and their role in determining the physicochemical characteristics of granular sludges in SBR system. Process Biochem. 2015;50(6):966-72. https://doi.org/10.1016/j.procb io.2015.02.020.

Taskin E, Bueno CC, Allegretta I, Terzano R, Rosa AH, Loffredo E. Multianalytical characterization of biochar and hydrochar produced from waste biomasses for environmental and agricultural applications. Chemosphere. 2019;233:422-30. https://doi. org/10.1016/j.chemosphere.2019.05.204.

Shen ZT, Zhang JZ, Hou DY, Tsang DCW, Ok YS, Alessi DS. Synthesis of MgO-coated corncob biochar and its application in lead stabilization in a soil washing residue. Environ Int. 2019;122:35762. https://doi.org/10.1016/j.envint.2018.11.045.

Shi JX, Fan XL, Tsang DCW, Wang F, Shen ZT, Hou DY, et al. Removal of lead by rice husk biochars produced at different temperatures and implications for their environmental utilizations. Chemosphere. 2019;235:825-31. https://doi.org/10.1016/j.chemo sphere.2019.06.237.

Wang J, Sun C, Lin BC, Huang QX, Ma ZY, Chi Y, et al. Micro-and mesoporous-enriched carbon materials prepared from a mixture of petroleum-derived oily sludge and biomass. Fuel Process Technol. 2018;171:140-7. https://doi.org/10.1016/j.fuproc.2017.11.013.

Wang Y, Wang QH, Li M, Yang YN, He W, Yan GX, et al. An alternative anaerobic treatment process for treatment of heavy oil refinery wastewater containing polar organics. Biochem. Eng. J. 2016;105(Part A):44-51. https://doi.org/10.1016/j. bej.2015.08.012.

Xiong YH, Liu Y. Essential roles of eDNA and AI-2 in aerobic granulation in sequencing batch reactors operated at different settling times. Appl Microbiol Biotechnol. 2012;93(6):2645-51. https:// doi.org/10.1007/s00253-011-3565-z.

Yang Q, Wang X, Luo W, Sun J, Xu Q, Chen F, et al.. Effectiveness and mechanisms of phosphate adsorption on iron-modified biochars derived from waste activated sludge. Bioresour Technol. 2018;247:537-44. https://doi.org/10.1016/j.biortech.2017.09.136.
Yang YY, Wang J, Liao JQ, Xie SG, Huang Y. Abundance and diversity of soil petroleum hydrocarbon-degrading microbial communities in oil exploring areas. Appl Microbiol Biotechnol. 2015;99(4):1935-46. https://doi.org/10.1007/s00253-014-6074-z.

Yuan HR, Lu T, Zhao DD, Huang HY, Noriyuki K, Chen Y. Influence of temperature on product distribution and biochar properties by municipal sludge pyrolysis. J Mater Cycles Waste Manag. 2013;15(3):357-61. https://doi.org/10.1007/s10163-013-0126-9.

Zhang BP, Xiong SJ, Xiao B, Yu DK, Jia XY. Mechanism of wet sewage sludge pyrolysis in a tubular furnace. Int J Hydrog Energy. 2011a;36(1):355-63. https://doi.org/10.1016/j.ijhyd ene.2010.05.100.

Zhang DJ, Li W, Hou C, Shen JY, Jiang XB, Sun XY, et al. Aerobic granulation accelerated by biochar for the treatment of refractory wastewater. Chem Eng J. 2017;314:88-97. https://doi. org/10.1016/j.cej.2016.12.128.

Zhang FZ, Wu KY, Zhou HT, Hu Y, Sergei P, Wu HZ, et al. Ozonation of aqueous phenol catalyzed by biochar produced from sludge obtained in the treatment of coking wastewater. J Environ Manag. 2018a;224:376-86. https://doi.org/10.1016/j.jenvm an.2018.07.038.

Zhang HM, He YL, Jiang T, Yang FL. Research on characteristics of aerobic granules treating petrochemical wastewater by acclimation and co-metabolism methods. Desalination. 2011b;279(1-3):6974. https://doi.org/10.1016/j.desal.2011.05.060.

Zhang LL, Wu ZJ, Shi YF, Chen LJ, Song YC, Juan YH. Inhibitory effects of aromatic compounds on soil nitrification. Pedosphere. 2010;20(3):326-33. https://doi.org/10.1016/S1002 $-0160(10) 60021-5$.

Zhang P, Zheng SL, Liu J, Wang BC, Liu FH, Feng YJ. Surface properties of activated sludge-derived biochar determine the facilitating effects on Geobacter co-cultures. Water Res. 2018b;142:441-51. https://doi.org/10.1016/j.watres.2018.05.058.

Zielinska A, Oleszczuk P, Charmas B, Skubiszewska-Zieba J, Pasieczna-Patkowska S. Effect of sewage sludge properties on the biochar characteristic. J Anal Appl Pyrolysis. 2015;112:201-13. https ://doi.org/10.1016/j.jaap.2015.01.025.

Zou JT, Pan JY, Wu SY, Qian MJ, He ZF, Wang BB, et al. Rapid control of activated sludge bulking and simultaneous acceleration of aerobic granulation by adding intact aerobic granular sludge. Sci Total Environ. 2019;674:105-13. https://doi.org/10.1016/j.scito tenv.2019.04.006. 